\title{
Antineoplastic therapy administration: Nursing intervention in the relief of suffering
}

\author{
Administração de terapia antineoplásica: intervenção de enfermagem no alívio do sofrimento \\ Administración de terapia antineoplásica: Intervención de enfermería en el alivio del sufrimiento
}

How to cite this article:

Sá E, Lopes MAP, Basto ML. Antineoplastic therapy administration: Nursing intervention in the relief of suffering. Rev Bras Enferm [Internet]. 2019;72(1):177-82. DOI: http://dx.doi.org/10.1590/0034-7167-2018-0639

Corresponding Author Eunice Sá

E-mail: esa@esel.pt

Submission: 09-04-2018

Approval: 11-10-2018

\begin{abstract}
Objective: To identify the nursing interventions with potential to act on the suffering and to evaluate the results of the nursing intervention designed. Method: We used a multi method study. After the identification of the scientific evidence and having found the supporting theory, the intervention process to relieve the suffering of hospitalized patients was modeled using the methodology of qualitative research. Then, training conditions were created for the implementation of the intervention Chemotherapy Administration as an Individualized Nursing Intervention, with a Quasi Experimental, longitudinal piloting study. Results: The patients of the experimental group showed values of suffering lower than the control group. Having finished the pilot study, we would return to qualitative research to understand the variation of some data. Final Considerations: The use of mixed methods of investigations allowed the understanding of the different components of drug chemotherapy administration as an individualized nursing intervention.
\end{abstract}

Descriptors: Stress, Psychological; Nursing Care; Patient-Centered Care; Bone Marrow Neoplasm; Antineoplastic Agents.

\section{RESUMO}

Objetivo: Identificar intervenções de enfermagem com o potencial de atuar sobre o sofrimento e avaliar os resultados da intervenção de enfermagem criada. Método: Uma abordagem de estudo multimétodo foi utilizada. Após identificar as evidências científicas e encontrar a teoria de apoio, o processo de intervenção para aliviar o sofrimento de pacientes hospitalizados foi modelado utilizando a metodologia da pesquisa qualitativa. Em seguida, foram criadas as condições de treinamento para a implementação da intervenção Administração da Quimioterapia como Intervenção de Enfermagem Individualizada, com estudo piloto quase experimental, longitudinal. Resultados: Os pacientes do grupo experimental apresentaram valores de sofrimento inferiores ao grupo controle. Após o término do estudo piloto, retornaríamos à pesquisa qualitativa para entender a variação de alguns dados. Considerações Finais: $\mathrm{O}$ uso de métodos mistos de pesquisa permitiu a compreensão dos diferentes componentes da administração da quimioterapia medicamentosa como uma intervenção de enfermagem individualizada.

Descritores: Estresse Psicológico; Cuidados de Enfermagem; Assistência Centrada no Paciente; Neoplasias da Medula Óssea; Antineoplásicos.

\section{RESUMEN}

Objetivo: Identificar las intervenciones de enfermería con potencial para actuar sobre el sufrimiento y evaluar los resultados de la intervención de enfermería diseñada. Método: Utilizamos un estudio de varios métodos. Tras identificarse la evidencia científica y determinarse su fundamentación teórica, se modeló el proceso de intervención para aliviar el sufrimiento de los pacientes hospitalizados, aplicándose metodología cuantitativa. Posteriormente, se crearon las condiciones de capacitación para implementar la intervención Administración de Quimioterapia como una Intervención de Enfermería Individualizada, con un estudio piloto longitudinal cuasi-experimental. Resultados: Los pacientes del grupo experimental mostraron valores de sufrimiento inferiores a los del grupo control. Habiendo finalizado la prueba piloto, habríamos de retomar la investigación cualitativa para comprender la variación de algunos datos. Consideraciones finales: La aplicación de métodos mixtos de investigación permitió comprender los diferentes componentes de la administración de la quimioterapia farmacológica como una intervención de enfermería individualizada.

Descriptores: Estrés Psicológico; Atención de Enfermería; Atención Dirigida al Paciente; Neoplasias de la Médula Ósea; Antineoplásicos. 


\section{INTRODUCTION}

Hemato-oncological disease as a chronic disease is characterized by alternation between remission and relapse. This process is virtually inevitable, and its unpredictability and uncertainty give another meaning to the term "survivor." This means that in the various stages, from diagnosis, remission, and relapse through the final stages of life, the disease can be a dynamic process of living with, through and beyond cancer $^{(1)}$. It has a negative impact in the person's life ${ }^{(2)}$, involving intensity and great suffering in all phases of the disease trajectory, from diagnosis to treatment, as well as in the remission and relapse phases $^{(3)}$.This suffering stems from the imminence of death and the stigma that is still associated with hemato-oncological disease. Patients and families live in agony and are tormented by uncertainty ${ }^{(4)}$, relapses, and fear of possible death, and suffering is therefore a constant companion As Wright ${ }^{(5)}$ indicated, suffering is therefore a constant companion.

Cytostatic chemotherapy is the most common treatment modality to control the disease, which from time to time ${ }^{(6-7)}$ requires long periods of hospitalization. The effects and complications of chemotherapy can reduce quality of life and be so debilitating that individuals are forced to suspend all other activities ${ }^{(8)}$.

Suffering, conceived as an individual, multidimensional, dynamic and negative phenomenon, incorporates all aspects of life, alienating interpersonal relationships and causing feelings of helplessness, and leading to loss of hope and meaning, and it's difficult to conceive and articulate this life experience ${ }^{(9-11)}$. Gameiro $^{(12)}$ described it as subjective experience of suffering in illness, and posited five dimensions: psychological, physical, existential, socio-relational suffering and positive experiences ${ }^{(13)}$. Another concept that is often linked to suffering is distress, which is an unpleasant multifactorial emotional experience that may include feelings of vulnerability, sadness, and fear, or even depression, anxiety, panic, social isolation ${ }^{(14)}$.

Administration and monitoring of therapeutic protocols are recognized as one of the domains of nursing intervention ${ }^{(15-17)}$. We believe that the large amounts of time spent in these activities can have therapeutic results if the professionals who carry them out mobilize their knowledge about the disease, the person and the environment. Also needed is a therapeutic intention and appropriate behaviors that are intrinsic to the values of the nursing profession ${ }^{(10-11,18-19)}$. Individualized care is a type of nursing care delivery that takes into account patients' personal characteristics and preferences, promoting patient participation and decisionmaking in their care ${ }^{(20-26)}$, in contrast to routine or standardized interventions in which all patients receive the same care.

\section{OBJECTIVE}

To identify nursing interventions with the potential to act on suffering and to evaluate the outcome of an individualized intervention.

The research question to be addressed was: Can the individualized administration of cytostatic drug therapy by nurses alleviate the suffering of hospitalized adult and elderly patients with hemato-oncological disease?

\section{METHOD}

The present study used a multi-method design following the stages of the methodological procedure to investigate complex health interventions ${ }^{(27)}$, and the criteria to ensure the quality reporting of these studies ${ }^{(28)}$. Development of this method was carried out in the following stages: development, feasibility / piloting, evaluation and implementation.

\section{Ethical aspects}

The institutional (Centro Hospitalar Lisboa Central) and individual ethical requirements were fulfilled.

\section{Study design, location of the study and study period}

The three studies $(1,2,3)$ were carried out in a clinical hematology unit in a Lisbon hospital. The study was carried out in the hospital wards for men and woman, over a period of four years.

At the stage of development designated as T0, we defined the problem with a literature review, based on which a paper was created $^{(29)}$. In addition, we performed two studies.

The first was an exploratory study (study 1, phase T0) to identify nursing interventions with the potential to act on the suffering of individuals with hemato-oncologic disease hospitalized in that context. We performed participant observation, informal individual interviews with patients and nurses, and written questionnaires for nurses, to identify and explain the components of the intervention, called Administration of Chemotherapy as a Nursing Intervention (AQT-I).

The descriptive study (study 2, phase T0) aimed to identify the nurses' perceptions of their practices regarding individualized care, using the Individualized Nursing Care Rating Scale - Nurses' Opinion $^{(30)}$ and the Scale of Evaluation of the Contextual Framework/Professional Practice Environment (RPPE) ${ }^{(31)}$. Based on the results, we identified the types, parameters and behaviors of the intervention, as well as the way to distribute and organize the different components of the intervention ${ }^{(27,32)}$, which enabled the modeling of the intervention (end-stage T0) described above.

\section{Population}

The study participants were the nurses on these wards and the patients admitted to the service during the study's time frame. Patient inclusion criteria were individuals undergoing antineoplastic chemotherapy, adults of any age, of both genders, with any diagnosis of hemato-oncological disease; there were no restrictions as to the time of diagnosis and/or treatment. Patients in the palliative phase of the disease were excluded. In study 3 we defined two groups of patients: an experimental group (EG) and a control group (CG), and their nurses. The EG was the target of the intervention described below.

\section{Study protocol}

The interaction guidelines for the intervention were developed with the participation of the five co-investigator nurses, who was selected from the following criteria: working exclusively on 
the morning shift from Monday to Friday; and continuity of the application of the therapeutic protocols to the same patients during 3 days. These criteria made it possible to ensure continuity of intervention by the same nurses to the same patients. This interaction guidelines explained the sequence of components and indicators to follow in order to achieve an individualized and client-centered intervention. Figure 1 outlines the steps.

The guidelines were also validated by three judges who are experts in the concepts and practices of the nursing care for people with cancer.

1- Prior to interaction - Diagnostic Assessment Process ${ }^{2}$ (access and gather information on the preferences and needs of the ill person ${ }^{1,3}$ )

2- During the interaction - Therapeutic Intervention Process²: promote autonomy, respect, comfort, confidence, security; encourage hope and perseverance ${ }^{2}$ (Suit ... and gives powerhow to develop interaction with people receiving treatment for antineoplastic chemotherapy, according to the principies of individualized and client-centered care')

3- End of the interaction (what to ask the patient and what to record after the interaction).

SUHONEN R, VÄLIMÄKI M, LEINO-KILPI H. (2008). A review of outcomes of individualised nursing interventions on adult patients. Journal of Clinical Nursing 17(7),843-860.

2 LOPES, M.I. (2006). A relação enfermeiro-doente como Intervenção terapêutica. Formasau Coimbra, p. 367

3 COLLIÉRE, M-F. (1999). Promover a vida. Da Prática das mulheres de virtude aos cuidados de enfermagem. Lisboa: SEP616-083 COL

Figure 1 - Theoretical assumptions to support construction of the script of the nursing interaction: Chemotherapy Administration as a Nursing (Individualized) Intervention (AQT-I)

STUDY DESIGN Adaptaded from Gulpers et al, 2010

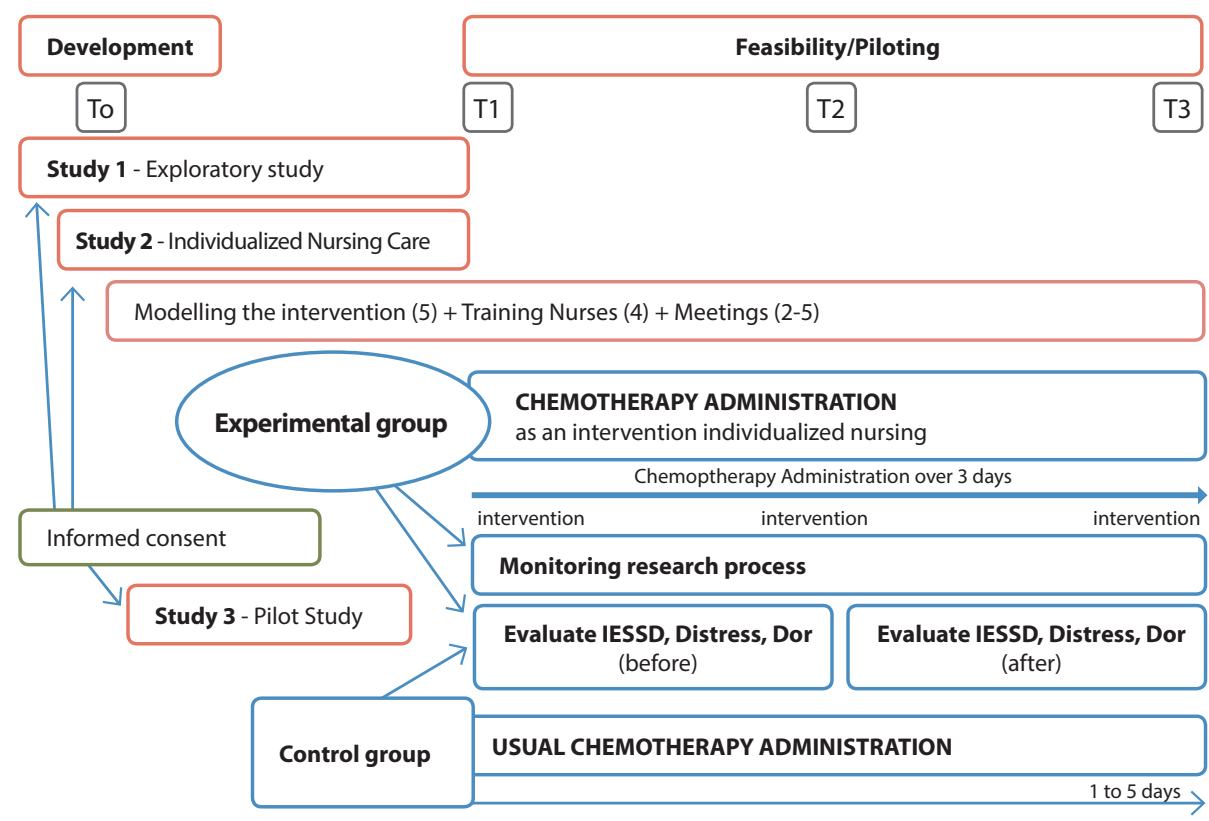

Figure 2 - Overall study design: exploratory study, descriptive and Quasi Experimental
In the feasibility/piloting stage, we carried out a quasi-experimental, longitudinal study in which the intervention described in the interaction guidelines was implemented by the same five nurses. This intervention was implemented for three consecutive days, exclusively in the morning shift from Monday to Friday, at Time 1 (T1), Time 2 (T2), and Time 3 (T3), as can be seen in Figure 2.

In order to identify the results of the intervention and the patients'levels of suffering, three instruments were used: Gameiro's Subjective Experiences of Suffering in Illness Inventory ${ }^{(12)}$ (IESSD), the Distress Thermometer ${ }^{(33)}$ and the Analog Scale of Pain ${ }^{(34)}$.These instruments were applied at two times. The first was before the intervention (pre) and was applied to all the patients in the study (CG and EG). The second was on the third day, after completing the third intervention (post), allowing comparison of the results.

In the control group (CG), the times of chemotherapy administration followed the usual functioning format, were performed by other nurses on the nursing care team, and were provided any day of the week.

The central hypothesis of the study was that there would be decreases in levels of distress, pain intensity, number of problems experience, and suffering in the experimental group between the pre- and post-intervention evaluations. It was also expected that there would be no statistically significant differences between the experimental group and the control group in the pre- and post-intervention evaluations for all dependent measures.

Quality criteria were used in the development, implementation and reporting of the intervention, following the recommendations of Equator Centre UK (TIDieR checklist, TREND Statement Checklist and CReDECI 2 checklist).

\section{Analysis of results and statistics}

The data from the interviews (for both patients and nurses) and questionnaires (only for nurses), as well as observation records, were organized by subject affinity in an open model and by the pairing strategy ${ }^{(35)}$.

The data (study 2 and 3) were analyzed using the Statistical Package for the Social Sciences (SPSS) (IBM).

\section{RESULTS}

The results of the literature review pointed to the importance of personcentered care, moving away from routines, and the advocacy of individuality of the sick person by nurses.

We categorized the interview data for nurses (total of 14) and patients (total of 12), the questionnaires for the nurses (total of 12 returned), and the records of observation of the administration of antineoplastic chemotherapy by the nurses (a total of 15 nurses), that were collected in study 1 . This qualitative analysis of the data yielded information about 
the basis of the nurses' objectives, which guided their practices and defined the following categories: promotion comfort, trust, hope and perseverance. The data were then compared and validated with the Therapeutic Intervention Process ${ }^{(36)}$.

The differences found in the quasi-experimental study (study 3 ) indicated that the mean levels of suffering (physical, psychological, existential and socio-relational), pain and distress in the experimental group were lower than in the control group. These positive results were based on two factors. The first was the method implemented in the intervention protocol (interaction script); the second was the individual work methods of the nurses in the care of the same patients and on a continuous basis. This ensured obtaining in-depth knowledge of the patients and levels of interaction with increasing proximity. We also found an increase in the mean number of problems reported between the two times of evaluation (pre- and post-intervention in the experimental group), as measured by the Distress Thermometer.

\section{DISCUSSION}

The quality of interactions that are repeated as often as the administration of therapy is expected to confer relief of the suffering of individuals, since the approach of nurses is no longer a mere technical act. Although these interactions derive from prescriptions created by other practitioners, the assumptions and behaviors of nurses in the course of these interactions are autonomous. We believe that care cannot be meaningful if the use of techniques does not remain integrated in the relational process $^{(37-38)}$. Therefore, a key premise of the present study was that there will be a dichotomy between technical and relational care in any type of care with greater technical requirements, such as the administration of cytostatics ${ }^{(10,16,19,36,39)}$.

The increase in the mean number of problems reported between the two times of evaluation (pre- and post-intervention in the experimental group), as measured by the Distress Thermometer, which resulted from this alignment, despite knowing that the care environment would not be very favorable to the expression of their suffering, makes patients report more concerns in writing than verbally to nurses ${ }^{(40)}$.

We emphasize the contribution of the qualitative study, which made more understandable what emerged from the context of the study ${ }^{(41)}$. The nurses who participate in the study revealed that they had knowledge about administering therapy, cancer, and patientcentered care. This helped them feel competent to provide useful information and convey to patients a sense of security, which was confirmed by the patients. The present study confirms the relevance of the privileged place occupied by nurses and other professionals in health teams in providing information and support during the administration of chemotherapy cycles ${ }^{(9,40,42)}$.

\section{Limitations of the study}

The limitations of the study were the difficulty of recruiting the sample and the dragging in time involved a small sample size, which made statistical significance difficult and does not allow generalization to the general patient population or other clinical contexts. In addition, radical changes in the context with regard to nursing records was another limitation, since it made them unfeasible as a way of extracting the indicators for evaluation of the intervention.

If nursing interventions in the administration of antineoplastics follow the theoretical assumptions of individualization of nursing care, it will reduce the suffering of individuals with hematooncological disease. It may reduce the sufferings of any other types of patients, as long as these therapeutic intentions are placed.

The nurses who participated in the study suggested that a grid format for a guide to the interaction during the AQT-I could be used to guide the intervention of novice nurses.

\section{Contributions to the fields of nursing and health care}

Despite the limitations of the study, it confirmed the importance of nursing care that is focused on the needs and feelings of ill persons, and not on their illness.

\section{FINAL CONSIDERATIONS}

After identifying nursing interventions with the potential for relieving suffering, the present study modeled an intervention and evaluated its viability and effectiveness. The administration of antineoplastic chemotherapy that is performed intentionally and integrated into the individual and unique experience of each ill person was shown to have positive effect, although without statistical significance. The results indicate that in order to achieve relief of suffering, nursing care should be centered on the personal characteristics of patients, integrated into their unique individual experiences, and that nursing interventions should be based on knowledge and intentionality.

The use of mixed research methods allowed optimization of the results as respecting a basic matrix. It also allowed understanding of the different components of the nursing intervention, taking into account the complexity inherent in the context and the actual nursing intervention, in the implementation and evaluation of Administration of Antineoplastic Chemotherapy, as a Nursing Intervention (Individualized).

\section{FUNDING}

This study was financed in part by the Research and Development Unit in Nursing (UI \& DE).

\section{REFERENCES}

1. NCCS: National Coalition for Cancer Survivorship [Internet]. Silver Spring (MD): National Coalition for Cancer Survivorship; c1995-2018 [cited 2018 Feb 18]. Available from: https://www.canceradvocacy.org/about-us/our-mission/

2. Pereira N, Botelho MAR. [Lived experience of colorectal cancer survivors after treatment with curative intent: systematic review of 
literature]. Pensar Enferm [Internet]. 2012 [cited 2018 Feb 18];16(2):31-50. Available from: http://pensarenfermagem.esel.pt/files/PE162_Artigo2_31-50.pdf Portuguese.

3. Ferrel BR, Coyle N. The nature of suffering and the goals of nursing. Oncol Nurs Forum [Internet]. 2008 [cited 2018 Feb 18];35(2):241-7. Available from: https://doi.org/10.1188/08.ONF.241-247

4. Mishel MH. Uncertainty in illness. Image J Nurs Sch [Internet]. 1988 [cited 2018 Dec 27];20(4): 225-32. Available from: https://doi. org/10.1111/j.1547-5069.1988.tb00082.x

5. Wright L. Espiritualidade, Sofrimento e Doença. Coimbra (PT): Ariadne; 2005. 127 p.

6. deWit S, Stromberg H, Dallred C. Medical-surgical nursing: concepts and practice. St Louis (MO): Elsevier; 2009. Chapter 2, Care of patients with cancer; 157-76.

7. Ciesla B. Hematologia na prática clínica. Loures (PT): Lusodidata; 2010. 366 p.

8. Wayman LM, Gaydos HB. Self-Transcending through suffering. J Hosp Palliat Nurs. 2005;7(5): 263-70.

9. Best M, Aldridge L, Butow P, Olver I, Webster F. Conceptual analysis of suffering in cancer: a systematic review. Psychooncology [Internet]. 2015 [cited 2018 Dec 27];24(9):977-86. Available from: https://doi.org/10.1002/pon.3795

10. Hale-Smith A, Park CL, Edmondson D. Measuring beliefs about suffering: development of the views of suffering scale. Psychol Assess [Internet]. 2012 [cited 2018 Dec 27];24(4):855-66. Available from: https://doi.org/10.1037/a0027399

11. Pavlish C, Brown-Saltzman K, Jakel P, Rounkle AM. Nurses' responses to ethical challenges in oncology practice: an ethnographic study. Clin J Oncol Nurs [Internet]. 2012 [cited 2018 Dec 27];16(6):592-600. Available from: https://doi.org/10.1188/12.CJON.592-600

12. Gameiro MH. Sofrimento na doença. Coimbra (PT): Quarteto; 1999. 194 p.

13. Gameiro MG. O sofrimento na doença: apresentação de um modelo facilitador do pensar o sofrimento e da organização das intervenções de alívio. Ciclo de colóquios. Cultura e doença mental. O poder do outro. Dor e sofrimento. 2006:135-53.

14. National Comprehensive Cancer Network [Internet]. NCCN Clinical practice guidelines for supportive care: distress management. Version 2.2018. Plymouth Meeting (PA): National Comprehensive Cancer Network; 2018 [cited 2018 Feb 18]. Available from: https://www.nccn.org/ patients/guidelines/distress/files/assets/basic-html/page-10.html

15. Benner P, Queirós AA, Belarmina L, Dias AS. De iniciado a perito: excelência e poder na prática de enfermagem. 2 ed. Coimbra (PT): Quarteto; 2001. $294 \mathrm{p}$.

16. Skalla KA, McCoy JP. Spiritual assessment of patients with cancer: the moral authority, vocational, aesthetic, social, and transcendent model. Oncol Nurs Forum [Internet]. 2006 [cited 2018 Dec 27];33(4):745-51. Available from: https://doi.org/10.1188/06.0NF.745-751

17. Meneses KD, McNees P, Loerzel VW, Su X, Zhang Y, Hassey LA. Transition from treatment to survivorship: effects of a psyclioeducationai intervention on quality of life in breast cancer survivors. Oncol Nurs Forum [Internet]. 2007 [cited 2018 Dec 27];34(5):1007-16. Available from: https://doi.org/10.1188/07.ONF.1007-1016

18. Watson J. Nursing: human science and human care: a theory of nursing. NLN Publ. 1988;(15-2236):1-104.

19. Best M, Aldridge L, Butow $P$, Olver I, Webster F. Treatment of holistic suffering in cancer: a systematic literature review. Palliat Med [Internet]. 2015 [cited 2018 Dec 28];29(10):885-98. Available from: doi:10.1177/0269216315581538

20. Suhonen R, Välimäki M, Leino-Kilpi H, Katajisto J. Testing the individualised care model. Scand J Caring Sci [Internet]. 2004 [cited 2018 Dec 28];18(1):27-36. Available from: https://doi.org/10.1111/j.1471-6712.2004.00255.x

21. Suhonen R, Leino-Kilpi H, Välimäki M. Development and psychometric properties of the individualised care scale. J Eval Clin Pract [Internet]. 2005 [cited 2018 Dec 28];11(1):7-20. Available from: https://doi.org/10.1111/j.1365-2753.2003.00481.x

22. Mårtensson G, Carlsson M, Lampic C. Do oncology nurses provide more Care to patients with high levels of emotional distress? Oncol Nurs Forum [Internet]. 2010 [cited 2018 Dec 28];37(1):e34-e42. Available from: https://doi.org/10.1188/10.ONF.E34-E42

23. Tay LH, Ang E, Hegney D. Nurses' perceptions of the barriers in effective communication with inpatient cancer adults in Singapore. $J$ Clin Nurs [Internet]. 2012 [cited 2018 Dec 28];21(17-18):2647-58. Available from: https://doi.org/10.1111/j.1365-2702.2011.03977.x

24. Charalambous A, Katajisto J, Välimäki M, Leino-Kilpi H, Suhonen R. Individualised care and the professional practice environment: nurses' perceptions. Int Nurs Rev [Internet]. 2010 [cited 2018 Dec 28];57(4):500-7. Available from: https://doi.org/10.1111/j.1466-7657.2010.00831.x

25. Sandeman G, Wells M. The meaning and significance of routine follow-up in lung cancer: a qualitative study of patients' experiences and interpretations. Eur J Oncol Nurs [Internet]. 2011 [cited 2018 Dec 28];15(4):339-46. Available from: https://doi.org/10.1016/j. ejon.2010.09.003

26. Suhonen R, Papastavrou E, Efstathiou G, Tsangari H, Jarasova D, Leino-kilpi H, et al. Patient satisfaction as an outcome of individualized nursing care. Scand J Caring Sci [Internet]. 2012 [cited 2018 Dec 28];26(2):372-80. Available from: https://doi. org/10.1111/j.1471-6712.2011.00943.x

27. Craig P, Dieppe P, Macintyre S, Michie S, Nazareth I, Petticrew M; Medical Research Council Guidance. Developing and evaluating complex interventions: the new Medical Research Council guidance. BMJ [Internet]. 2008 [cited 2018 Dec 28];337:a1655. Available from: https://doi. org/10.1136/bmj.a1655

28. Möhler R, Bartoszek G, Köpke S, Meyer G. Proposed criteria for reporting the development and evaluation of complex interventions in 
healthcare (CReDECI): guideline development. Int J Nurs Stud [Internet]. 2012 [cited 2018 Dec 28];49(1):40-6. Available from: https://doi. org/10.1016/j.jinurstu.2011.08.003

29. Sá E. A contribuição da enfermagem para aliviar o sofrimento do doente hemato-oncológico: revisão da literatura. Pensar Enferm [Internet]. 2010 [cited 2018 Feb 18];14(2):55-69. Available from: http://pensarenfermagem.esel.pt/files/2010_14_2_55-69.pdf

30. Suhonen R, Schmidt LA, Radwin L. Measuring individualized nursing care: assessment of reliability and validity of three scales. J Adv Nurs [Internet]. 2007 [cited 2018 Dec 28];59(1):77-85. Available from: https://doi.org/10.1111/j.1365-2648.2007.04282.x

31. Erikson Jl, Duffy ME, Gibbons MP, Fitzmaurice J, Ditomassi M, Jones D. Contextual Framework/Professional Practice Environment (EPRP). J Nurs Scholarsh. 2004;36(3):279-285.

32. Craig P, Dieppe P, Macintyre S, Michie S, Nazareth I, Petticrew M. Developing and evaluating complex intervention: The New Medical Research Council Guidance. Int J Nurs Stud [Internet]. 2013 [cited 2017 Feb 20];50(5):587-92. Available from: http://dx.doi.org/10.1016/j. ijnurstu.2012.09.009

33. Bacalhau R. Termómetro de distress. Lisboa: CROL, SA; 2004. Translation from the National Comprehensive Cancer Network.

34. Ministério da Saúde (PT), Direcção-Geral da Saúde. Circular normativa n. 09/DGCG. A Dor como 5 sinal vital. Registo sistemático da intensidade da dor [Internet]. Lisboa: Direcção-Geral da Saúde; 2003 [cited 2003 Jun 14]. Available from: https://www.dgs.pt/directrizes-dadgs/normas-e-circulares-normativas/circular-normativa-n-9dgcg-de-14062003.aspx

35. Bardin L. Análise de conteúdo. Lisboa: Edições 70; 2015. 281 p.

36. Lopes MJ. A relação enfermeiro: doente como intervenção terapêutica: proposta de uma teoria de médio alcance. Coimbra (PT): Formasau; 2006. $368 \mathrm{p}$.

37. Collière MF. Promover a vida: da prática das mulheres de virtude aos cuidados de enfermagem. Lisboa: Lidel; 1999. 385 p.

38. McCormack B, McCance TV. Development of a framework for person-centred nursing. J Adv Nurs [Internet]. 2006 [cited 2017 Feb 20];56(5):472-9. Available from: https://doi.org/10.1111/j.1365-2648.2006.04042.x

39. Kvåle K, Bondevik M. Patients' perceptions of the importance of nurses' knowledge about cancer and its treatment for quality nursing care. Oncol Nurs Forum [Internet]. 2010 [cited 2017 Feb 20];37(4):436-42. Available from: https://doi.org/10.1188/10.0NF.436-442

40. Madden J. The problem of distress in patients with cancer: more effective assessment. Clin J Oncol Nurs [Internet]. 2006 [cited 2017 Feb 20];10(5):615-9. Available from: https://doi.org/10.1188/06.CJON.615-619

41. Fox P, Butler M, Coughlan B, Murray M, Boland N, Hanan T, et al. Using a mixed methods to investigate complementary alternative medicine (CAM) use among women with breast cancer in Ireland. Eur J Oncol Nurs [Internet]. 2013 [cited 2017 Feb 20];17(4):490-7. Available from: https://doi.org/10.1016/j.ejon.2012.10.008

42. Duhamel F, Dupuis F. Guaranteed returns: investing in conversations with families of patients with cancer. Clin J Oncol Nurs [Internet]. 2004 [cited 2017 Feb 20];8(1):68-71. Available from: https://doi.org/10.1188/04.CJON.68-71 